\title{
İstanbul'daki Kadın Kooperatiflerinin Kadın Yoksulluğuna Etkisi ${ }^{1}$
}

\author{
DOI: 10.26466/opus.590744 \\ *
}

\begin{abstract}
H. Yunus Taş* - Esra Nur Kazar**
*Prof.. Dr, Yalova Üniversitesi, İktisadi ve İdari Bilimler Fakültesi, Yalova/ Türkiye E-Posta: hyunustas@gmail.com ORCID: 0000-0003-3163-9416

**Araş. Gör. Yalova Üniversitesi, İktisadi ve İdari Bilimler Fakültesi, Yalova/ Türkiye E-Posta: esranur.kazar@hotmail.com.tr ORCID: $\underline{0000-0001-5727-0667}$
\end{abstract}

\section{Öz}

Kadın yoksulluğu kavramı, yoksulluğu cinsiyet açısından değerlendirmekte olup, kadınların erkeklere nazaran yoksulluğu daha derinden ve şiddetli yaşadıkların ifade etmek için kullanılmaktadır. Kadın yoksulluğunun temel nedenleri incelendiğinde bunlar, toplumsal cinsiyet, hane içi eşitsizlikler, eğitim ve kadının işgücü piyasasındaki konumudur. Bu bağlamda, kadın kooperatifleri kadın yoksulluğunu azaltmada veya önlemede bir sosyal politika aracı olarak düşünülmektedir. Bu araştırmada, kadın kooperatiflerinin kadın yoksulluğuna olan etkisini kadın kooperatifi çalışanlarına yönelik yapılan görüşmeler kapsamında analiz edilmesi amaçlanmıştır. Bu temel amaç doğrultusunda, İstanbul ilinde faaliyette bulunan 6 kadın kooperatifinden toplam 18 kadın çalışana yarı yapılandırılmış görüşme formu, uygulanmıştır. Görüşmelerin analizinde, "MAXQDA 2018" nitel veri analizi programı kullanılmıştır. Kadın kooperatifi çalışanları ile yapılan yarı yapılandırılmış görüşme analizi sonucunda, katılımcıların çoğu kooperatifin maddi fayda yerine sosyal fayda yönünü vurguladıkları, kadın kooperatifi sayesinde kendilerini daha mutlu, sosyal, özgüvenli ve güçlü hissettikleri, yoksul hissetmedikleri; kooperatif olarak ise maddi destek, takım ruhu, sürdürülebilir pazarlama ve SGK hakkı yoksunluğu yaşadıkları anlaşılmiştır.

Anahtar Kelimeler: Yoksulluk, Kadın Yoksulluğu, Kadın Kooperatifi

\footnotetext{
${ }^{1}$ Bu makale, sorumlu yazarın "Kadın Yoksulluğunu Azaltmada Kadın Kooperatiflerinin Rolü: ístanbul ve Bursa Örneği" isimli doktora tezinin bir kısmından üretilmiştir.
} 


\title{
The Effect of Women's Cooperatives in İstanbul on Women's Poverty
}

\begin{abstract}
The concept of female poverty evaluates poverty in terms of gender and is used to express that women experience poverty more deeply and more violently than men. When the main causes of female poverty are examined, these are gender, inequalities in the household, education and women's position in the labor market. In this context, women's co-operatives are considered as a social policy tool in reducing or preventing women's poverty. The aim of this study is to analyze the impact of women's co-operatives on women's poverty in the context of interviews conducted with women's co-operatives. For this purpose, a semi-structured interview form was administered to 18 female employees from 6 women's cooperatives operating in Istanbul. MAXQDA 2018 qualitative data analysis program was used in the analysis of the interviews. As a result of the semi-structured interview analysis conducted with women's cooperative workers, most of the participants emphasized the social benefit aspect of the cooperative instead of financial benefit. They stated that they felt happier, social, confident and strong and did not feel poor thanks to the women's cooperative. As for the cooperative, they were deprived of financial support, team spirit, sustainable marketing and SSI right.
\end{abstract}

Keywords: Poverty, Women Poverty, Women Cooperative 


\section{Giriş}

Yoksulluk kavramı, belirli bir standart tanımı olmayan çok boyutlu bir kavramdır. Yoksulluk kavramına atfedilen değerlerin farklı zamanda, kültürde, toplumda ve hatta kişiden kişiye değişebilir özellikler taşıması bu kavramı standart bir tanım içerisinde sınırlandırmayı güçleştirmiştir (Arabacı, 2014, s.182). Bu sebeple, yoksulluk kavramına ait bir tanımın yapılmasında kişilerin yoksulluğa bakış açıları yani yoksulluk kriterleri önem kazanmıştır. Yoksulluğa dair yapılan tanımlamalara bakıldı̆̆ında en genel anlamda maddi/gelir yetersizliğinin baz alınarak oluşturulan mutlak yoksulluk ve göreli yoksulluk tanımları akla gelmektedir. Maddi/gelir yetersizliğinin yanı sıra, insanın refahını, yaşadığı mekanı, cinsiyetini ve daha bir çok farklı kriteri dikkate alan farklı yoksulluk tanımları mevcuttur. Yoksulluğun bu denli farklı boyutlarının olması neticesinde, yoksulluk için insanın maddi ve/veya manevi ihtiyaçlarından yoksun olması durumudur denilebilir. Yoksulluk insanlar için bir nevi yoksunluklar halidir.

Yoksulluğa dair tanımlar sanayi devriminden günümüze değin, farklı paradigmaların etkisinde kalarak birçok farklı temel vurguyu barındırmıştır. Bazı dönemlerde çalışma, ya da ekonomik büyüme vurgusu yapılmış diğer bazı dönemlerde ise kişisel gelir veya tüketim vurgusu üzerinden tanımlanmaya çalışılmıştır (Ulutaş, 2009, s.25). Günümüzde yoksulluğun tipik tanımı, kişi başına düşen gelir ve yoksulluk sınırının altında yaşayan insan sayısı ile ilgili tahminlere dayandırılmaktadır. Yoksulluk, gelire dayalı yapılan tanımdan çok daha fazlasını kapsayan bir olgudur. Bu dar tanım, bireylerin sosyal dışlanmalarını ve kırılganlık deneyimlerini, insan haklarına dair güçlendirme, fırsat, kapasite ve güvenlik gibi temel hakları göz ardı etmektedir (Sicchia ve Maclean, 2006, s.69). Bu bağlamda, toplumsal cinsiyetin neden olduğu yoksulluk ve yoksulluk deneyimleri yoksulluk tanımında yer almamaktadır (Ulutaş, 2009, s.26). Günümüzde her ne kadar BM tarafından toplumsal cinsiyete duyarlı göstergeler hazırlanıp yayınlansa da toplumsal cinsiyete duyarlı verilerde bir kıtlık söz konusudur. Kadınların yaşadıkları cinsiyet ayrımcılığı ve eşitsizliğin çoklu katmanları sebebiyle kadınlar yoksulluğa karşı daha savunmasız kalmaktadır ve erkeklere kıyasla yoksulluk deneyimleri daha şiddetli olmaktadır (Sicchia ve Maclean, 2006, s.69). 


\section{Kadın Yoksulluğu Kavramı}

Kadın yoksulluğu veya yoksulluğun kadınlaşması (feminization of poverty) kavramı, ilk olarak Diane Pearce tarafından 1978 yılında kullanılmıştır. Yoksulluğun kadınlaşması kavramı, bu dönemde, Amerika'daki yoksulların 3'te 2'sinin kadınlardan oluşması ve işgücüne katılan kadın işgücünün artmasına rağmen, 1950-70 döneminde kadınların ekonomik olarak daha da kötüleşmesi neticesinde bu duruma dikkat çekmek amacıyla kullanılmıştır. 1995'te gerçekleştirilen 4. Dünya Kadın Konferansı Eylem Planı'nda da yoksulluğun kadınlaşması kavramı kullanılmıştır (Gerşil, 2015, s.162). Kadın yoksulluğu yani yoksulluğun feminizasyonu, toplumsal cinsiyet ile yoksulluğun dügünü olarak da ifade edilmiştir (Chant, 2008, s.172).

Kadın yoksulluğu kavramının ön plana çıkmasına sebep olan temel unsurlar ise, nicelik olarak yoksul kadınların yoksul erkekleri geçmesi, kadın hane halkı reislerinin artması, niteliksel olarak kadınların yoksulluğu erkeklerden daha derin ve şiddetli yaşamalarıdır (Kardam ve Yüksel, 2004, s.46).

Yoksulluk kavramının cinsiyet açısından incelenmesinde, Amerika'daki yoksulluk oranının yalnız yaşayan kadınlardan ve tek ebeveynli kadın ve çocuk olmak üzere oluşan ailelerde yüksek çıkmasını etkisi olmuştur. Boşanmaların artması, aile yapısındaki değişiklikler, çocukların sadece anneler tarafından bakılması gibi sebepler neticesinde yoksulluğun kadınlaşması kavramının kullanılması ihtiyacı doğmuştur (Gerşil, 2015, s.162).

Tıpkı yoksulluk gibi kadın yoksulluğu ile mücadelede kadın yoksulluğunun nedenlerinin doğru bir şekilde tespit edilmesi gerekmektedir. Kadın yoksulluğunun temel nedenleri incelendiğinde bunlar, toplumsal cinsiyet, hane içi eşitsizlikler, eğitim ve işgücü piyasasındaki konumudur (Topalhan ve Yeşilkaya, 2017, s.58).

\section{Kooperatifçilik ve Kadın kooperatifçiliği}

Kooperatifler, yoksullukla mücadele etmede önemli bir sosyal politika araçlarından biridir. Kooperatifler, tüzel kişiliği haiz olmak üzere ortaklarının belirli ekonomik menfaatlerini ve özellikle meslek ve geçimlerine ait 
ihtiyaçlarını işgücü ve parasal katkılarıyla karşılıklı yardım, dayanışma ve kefalet sureti ile sağlayıp korumak amacıyla gerçek ve tüzel kişiler tarafından kurulan değişir ortaklı ve değişir sermayeli ortaklıklardır (1163 Sayılı Kanun madde 1). Kooperatifçiliğin amacı karşılıklı yardım ve dayanışma içerisinde ekonomik ve sosyal menfaatler elde etmektir.

Kooperatifçiliğin ekonomik bir hareket olarak ortaya çıtığı dönem 19. yüzyıl olmuştur. Ekonomik ve sosyal ihtiyaçların karşılanma gereksiniminden dolayı dayanışma sonucunda ortaya çıan kooperatifçilik hareketi 1844 yılında, İngiltere'nin Rochdale Kasabası'nda ortaya çıkmıştır (Koçtürk, 2006, s.120). İngiltere' de kooperatifçilik hareketi öncelikle tüketim kooperatifleri türünde ortaya çımış daha sonra üretim ve kredi kooperatifleri türünde devam ederek Almanya'ya ve Fransa'ya daha sonra bu ülkelerden de tüm dünyaya yayılmıştır (Semerci, 2015, s.67).

Ekonomik ve siyasi bir birlik olan Avrupa Birliği'nde yaklaşık 250.000 kooperatif işletmesi bulunmaktadır. Böylelikle her üç Avrupa Birliği vatandaşından biri kooperatif işletmesinin ortağ 1 konumundadır. Kooperatifler Avrupa Birliği genelinde 5,4 milyar kişiye de istihdam sağlamaktadır (G-20 Ülkelerinde Kooperatifçilik, 2015, s.30).

Avrupa Birliği'ne üye olan ülkelerde kooperatifler önemli pazarlar elde etmektedir. Örneğin, tarım sektöründe ülke genelinde Hollanda' da \% 83, Finlandiya'da \% 79, İtalya' da \% 55 ve Fransa' da \% 50'dir (G-20 Ülkelerinde Kooperatifçilik, 2015, s.30).

Türkiye'de gerçek manada kooperatifçilik hareketi ise, II. Meşrutiyet döneminde, Mithat Paşa öncülüğünde başlamıştır. Mithat Paşa, devlete ait olan boş arazilerde tarım yapılıp elde edilen ürünlerin satışından bir sandık kurulabileceğini ve köylüleri tefecilerin elinden kurtarabileceği amacıyla memleket sandıklarını kurmuştur. Memleket Sandıkları 29 maddelik Memleket Sandıkları Nizamnamesi ile kurulmuştur (Kocabaş, 2003, s.16-17). Türkiye'de Anayasada kooperatiflere yönelik ilk yasal düzenleme 1961 Anayasası'nın 51. maddesinde yer almaktadır. İlgili maddede, “ Devlet, kooperatifçiliğin gelişmesini sağlayacak tedbirleri alır." ifadesi geçmektedir (1961 T.C. Anayasası). Türkiye Cumhuriyeti Anayasası d1şında, Kooperatiflere yönelik oluşturulan ilk kanun 1969 yılında 1163 sayılı kooperatifler kanunudur. Bunun dışında, 1972 yılında 1581 sayılı Tarım Kredi Kooperatifleri ve Birlikleri Kanunu ile 2000 yılında 4572 sayılı 
Tarım Satış Kooperatifleri ve Birlikleri Kanunu yürürlüğe girmiştir. Kooperatif türlerinden biri olan kadın kooperatiflerine yönelik tek tip örnek ana 2011 yılından hazırlanmaya başlanmıştır (Kooperatifçilik ve Kadın Kooperatifleri, 2012, s.11).

Kadın kooperatifleri, ortakların ekonomik, sosyal ve kültürel ihtiyaçlarını karşılamak amacı taşıyan ve bu adımda atılan girişimleri destekleyen çok ortaklı demokratik ve şeffaf kurumlardır (Kadın Girişimi ve İşletme Kooperatifi Ana sözleşmesi, 2012, s.3).

Türkiye'de kadın kooperatiflerinin kuruluşu KEDV' in desteğiyle 2001 yılında kurulmuş olup günümüze kadar 60 kadın kooperatifinin kurulmasına öncülük etmişlerdir (Serinikli, 2016, s.601). Kadın kooperatifleşmesi sayesinde atıl durumda ama yetenekli kadınların el becerilerini kullanarak gıda, tasarım ürünlerine yönelik üretimde bulunması sağlanmaktadir.

\section{Yöntem}

Bu çalışmanın amacı, kadın yoksulluğu ile mücadelede aktif bir sosyal politika aracı olarak kadın kooperatiflerinin etkisini incelemektir. Bu bağlamda, bu çalışmada nitel veri toplama tekniğinden biri olan derinlemesine görüşme yöntemi seçilmiştir. Derinlemesine görüşme, açı uçlu soruların yer aldığı ve görüşmecinin kişisel görüşlerini aktardığı bir metottur. Derinlemesine görüşmenin amacı görüşmeye katılanların kişisel görüşlerinin altında yatan sebeplere ulaşmaktır (Baş ve Akturan, 2017, s. 113). Derinlemesine görüşmeler, yapılandırılmış, yarı yapılandırılmış ve yapılandırılmamış olarak sınıflandırılmaktadır. Bu çalışmada, derinlemesine görüşme tekniklerinden biri olan yarı yapılandırılmış görüşme tekniği uygulanmıştır. Çalışmanın örneklemi ise, amacına yönelik örneklemdir. İstanbul'daki kadın kooperatiflerinde çalışan 18 katılımcıya dokuz sorudan oluşan yarı yapılandırılmış görüşme formu uygulanmıştır. Bu çalışmada uygulanan yarı yapılandırılmış görüşme formunda, katılımc1ların kooperatif ve yoksulluk algıları ile kooperatifin kendilerine olan maddi ve manevi katkısını değerlendirebilmek için aşağıda belirtilen sorulara yanıt aranmıştır:

- Kooperatif denilince aklınıza ilk ne geliyor?

- Kooperatife katılım gerekçeniz nedir? 
- Kooperatiften aylık ne kadar gelir elde ediyorsunuz?

- Kooperatif gelirinizden memnun musunuz?

- Kooperatifteki çalışma arkadaşlarınızın size bir katkısı olduğunu düşünüyor musunuz?

- Kooperatifte çalışmanızın size bir katkısı olduğunu düşünüyor musunuz?

- Size göre yoksulluk nedir?

- Kendinizi yoksul hissediyor musunuz?

- Kooperatifinizde hangi eksiklik tamamlansa daha mutlu olursunuz?

$\mathrm{Bu}$ araştırma sorularının yöneltildiği görüşmelerin süresi 5-15 dakika arasında değişmiştir. Mülakat aracıllğ̆ ile elde edilen veriler ise MAXQDA 2018 programı kullanılarak betimsel analiz yapılmıştır.

\section{Bulgular}

Gerçekleştirilen nitel araştırma sonucunda elde edilen veriler değerlendirildiğinde toplamda dokuz araştırma sorusuna verilen cevaplar ve detayları bu bölümde yer alacaktır.

Tablo 1. Katılımcıların Demografik Özellikleri

\begin{tabular}{|c|c|c|c|c|}
\hline Katılımcı & Yaş & Medeni Durum & Eğitim Düzeyi & $\begin{array}{c}\text { Kooperatifteki } \\
\text { Faaliyeti }\end{array}$ \\
\hline K1 & 54 & Bekar & Lise & Tarım \\
\hline K2 & 59 & Evli & Üniversite & El İşi Ürünleri \\
\hline K3 & 61 & Bekar & Lise & El İşi Ürünleri \\
\hline K4 & 55 & Evli & Lise & El İşi Ürünleri \\
\hline K5 & 42 & Evli & İlköğretim & El İşi Ürünleri \\
\hline K6 & 41 & Evli & İlköğretim & El İşi Ürünleri \\
\hline K7 & 63 & Evli & Lise & Engelli Eğitimi \\
\hline K8 & 54 & Bekar & Lise & Tarım \\
\hline К9 & 62 & Bekar & Üniversite & El İşi Ürünleri \\
\hline K10 & 57 & Evli & İköğretim & El İşi Ürünleri \\
\hline K11 & 66 & Bekar & Lise & El İşi Ürünleri \\
\hline K12 & 60 & Evli & İlköğretim & El İşi Ürünleri \\
\hline K13 & 42 & Evli & İlköğretim & El İşi Ürünleri \\
\hline K14 & 56 & Bekar & Lise & El İşi Ürünleri \\
\hline K15 & 50 & Bekar & Lise & El İşi Ürünleri \\
\hline K16 & 40 & Evli & Lise & El İşi Ürünleri \\
\hline K17 & 54 & Evli & İlköğretim & El İşi Ürünleri \\
\hline K18 & 60 & Bekar & Lise & Tarım \\
\hline
\end{tabular}


On sekiz görüşme sonucu dokuz araştırma sorusuna verilen cevaplar için yirmi yedi kodlama yapılmıştır. Nitel araştırmaya katılan katılımcıların demografik özellikleri görüşme sırasına göre aşağıdaki gibi belirtilmiştir:

\section{Katılımcıların Kooperatif Algısı}

Katılımcilara kooperatif denilince aklınıza ilk ne geliyor sorusu sorulduğunda elde edilen veriler neticesinde kooperatif algısı kategorisi altında sosyal fayda ve ekonomik özgürlük olmak üzere iki farklı kod oluşturulmuştur.

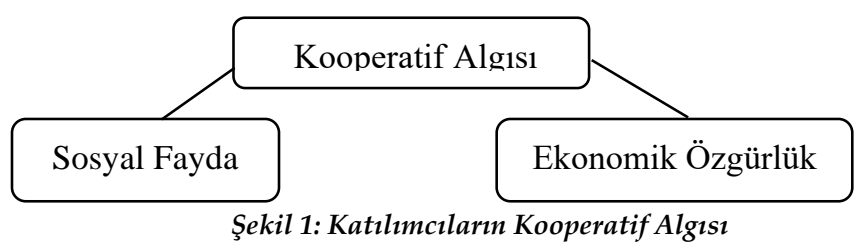

Katılımcılara kooperatif denilince aklınıza ilk ne geliyor sorusu sorulduğunda katılımcıların çoğunluğu kooperatifin sosyal fayda yönünü vurguladığı anlaşılmıştır. Bu bağlamda, sosyal fayda kodu altında ayrıca elde edilen veriler neticesinde yardımseverlik, dayanışma ve kişisel gelişim olmak üzere üç alt kod daha oluşturulmuştur.

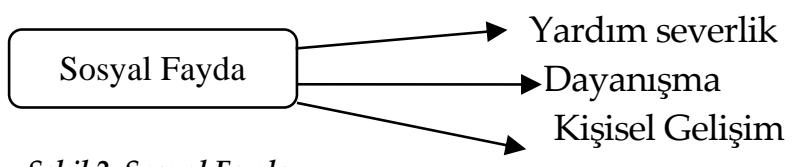

Şekil 2: Sosyal Fayda

Katılımcılardan elde edilen görüşme sonucu yardımseverlik temasına vurgu yapan görüşler aşağıda belirtilmiştir:

"Hem kendime hem çevreme faydalı olmak için hem yediğime içtiğime dikkat etmek için, çoluğuma çocuğuma faydalı olmak için. Kooperatif öyle bir şey ki benim kendi çorbama koyduğum tuzumun nereden geldiğini bilmem lazım. Kendi ektiğimi biçtiğimi ürettiğimi hem kendine çevreme ve evlatlarımın sağlığı için çok önemlidir. Benim için kooperatif toplumsal bir değerdir" (K1). 
Şeklinde görüşlerini belirten K1, kooperatif sayesinde ailesine çevresine yardım yapabileceği bir kurum olarak tanımlamaktadır. K8 de kooperatifin kadınlar için bir yardım etme kurumu olduğunu şu şekilde belirtmiştir:

"Benim için çok şey demek. Birkaç kelime ile ifade etmem çok zor. Kadınlara bir çare demektir kooperatif. Kadınların elinden tutmak demektir. Sosyal paylaşım demektir. Azınlıkta olan insanlara yardım eli uzatmak ve istihdam demek" (K8).

Kooperatif algısını değerlendirmek amacıyla oluşturulan sosyal fayda kodu altında da dayanışma alt kodu oluşturulmuştur. Katılımcılardan elde edilen görüşme sonucu dayanışma temasına vurgu yapan görüşler aşağıda belirtilmiştir:

"Benim için kız kardeşlik demektir. Hepimiz kız kardeşiz. Birlikte kurduk kooperatifi. Kadınlar Yerel yönetime katılıyor programı ile birlikte bir araya geldik. Çevremizi bir şeyle değiştirmek için başladık. İlk amacımız satış yapmak değildi. Bir yuva olabilir mi, farkındalık yaratabilir miyiz? Bir anket yaptık. Kadınlar çocukların yuvaya bırakarak çalışabilecekleri ya da kendilerine uygun bir yerde satıs yapabilecekleri bir yer istiyorlardı. Biz yuva yapamadik. Ama Belediye bizim anketi de ciddiye alarak tek yuva varken şuan 13 yuvaya çıtı. Bizim anketimiz farkındalık yarattı. Kadın Ekonomisi Pazarı ile de kadınlarm hem ekonomik hem sosyal hayata katılmalarını sağlıyoruz. Bunun için girişimcilik eğitimi yaptık. Yani bir staj gibi bir haftaya kadar tezgah açabilirsiniz ürünlerinizi satabilirsiniz dedik. Kimse gelmedi. Baya bir kadına ulaştık girişimcilik eğitimi ile yaklaşık 500 kadına ulaştı" (K2).

Katılımcı 2, kooperatifçiliği bir kız kardeşlik olarak tanımlayarak birlikte dayanışma içerisinde olduklarını hem çevreleri için hem kendileri için dayanışmanın faydasını vurgulamaktadır.

Kooperatif algısını değerlendirmek amacıyla oluşturulan sosyal fayda kodu altında da Kişisel Gelişim alt kodu oluşturulmuştur. Katılımcılardan elde edilen görüşme sonucu kişisel gelişim temasına vurgu yapan görüşler aşağıda belirtilmiştir:

Katılımcı 12, kooperatifçiliği kişisel gelişim ile bağdaştırarak görüşlerini şu şekilde belirtmiştir:

"İnsanın kendini geliştirmesi demektir. Sosyal faaliyetlerini geliştirmesi, kendine güvenmesidir. Başarılı olmasıdır. Maddi ve manevi olarak kendini geliştirmesidir. Her şeyi gördüm. Arkadaşlıkları, işi ve dostlukları gördüm" (K12). 
Katılımcı 16 ise, kooperatifçiliği kişisel gelişimi için kendine vakit ay1rabildiği bir alan olarak değerlendirerek kooperatifçiliğe yönelik algısını şu şekilde belirtmiştir:

"Benim için sosyallik demek çünkü otizmli bir kızım var. Bu yüzden sinırlı bir sosyal yaşantım var. Kooperatif benim kendime ayırdığım bir zaman açıkçası" (K16).

Katılımcılara kooperatif denilince aklınıza ilk ne geliyor sorusu sorulduğunda katılımcıların bir kısmı kooperatifin ekonomik özgürlük demek olduğunu vurgulamışlardır. Bu bağlamda, katılımcılardan elde edilen görüşme sonucu ekonomik özgürlük vurgusu yapan görüşler aşağıda belirtilmiştir:

"Ben geldiğimde burasının kooperatif olduğundan haberim bile yoktu. Sonradan öğrendim kadınlarm bir araya gelip para kazandığı bir yer demek" (K5).

"Evden kaçış noktam benim için. Kafam rahat burada. Ekonomik özgürlüğüm demek" (K14).

\section{Katılımcıların Kooperatife Katılım Gerekçesi}

Katılımcılara kooperatife katılım gerekçeniz nedir şeklinde sorusu sorulduğunda elde edilen veriler neticesinde kooperatife katılım gerekçesi kategorisi altında birlikte üretim yapmak, farkındalık yaratmak, sosyalleşmek, maddi ihtiyaç olmak üzere dört farklı kod oluşturulmuştur.

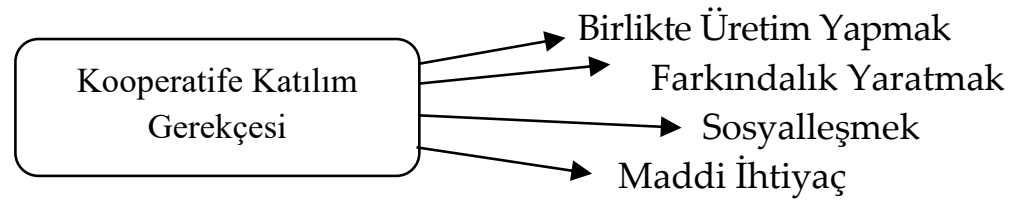

Şekil 3: Kooperatife Katılım Gerekçesi

Katılımcılara kooperatife katılım gerekçeniz nedir sorusu sorulduğunda katılımcların bir kısmı birlikte üretim yapmak olduğunu vurgulamışlardır. Bu bağlamda, katılımcılardan elde edilen görüşme sonucu birlikte üretim yapmak temasına vurgusu yapan görüşler aşağıda belirtilmiştir:

Katılımcı 1, birlikte üretim yaparak üretilen ürünlerin daha güzel olduğunu şu şekilde belirtmiştir: 
"Yalnız insanın bir yerde hevesi kırlliyor. Hep beraber olunca bir çok şeyi beraber yapıyorsun. Mesela benim bilgi birikimimle ben ă̆aç aşısı ve küçük hobi bahçesi yapabilirim. Ama kalabalık olunca hep beraber herkesin bilgisini birleştirince hem yapacağım işi çoğaltırım hem de etrafimdaki insanlara daha faydah olabilirim. Çünkü biz eğitim vermeyi de düşünüyoruz" (K1).

Katılımc1 4 ise, "Kadınlarm birlikte hareket edebilmeleri için ihtiyaç vardı bende katıldım" şeklinde görüşünü belirterek kadınlar ile birlikte üretim yapmayı istedikleri için kooperatife katıldığını dile getirmiştir.

Katılımcllara kooperatife katılım gerekçeniz nedir sorusu sorulduğunda katılımcıların bir kısmı farkındalık yaratmak olduğunu vurgulamıştır. Bu bağlamda, katılımcılardan elde edilen görüşme sonucu birlikte farkındalık yaratmak temasına vurgusu yapan görüşler aşağıda belirtilmiştir:

Katılımcı 2, kooperatife katılım gerekçesini farkındalık yaratmak adı altında görüş bildirirken aynı zamanda sosyalleşmeye de katkısı olduğunu şu şekilde belirtmiştir:

"Çevrede farkındalık yaratmak. Kadınların sosyal hayata katılmasını cinsiyet eşitliği diyebilirim. Sokak lambaları yanmıyorsa kadınların hayatın etkiliyor. Sular akmıyorsa kadınların hayatın etkiliyor. Yerel yönetimi nasıl yönlendirebiliriz. Kadınlar olarak kadınların ihtiyaçların yine biz biliyoruz. Nasıl çz̈züme ulaştırabiliriz. O zamanlar hatta en iyi çözümü o sorunlar yaşayanlar bilir diye sloganımız vardı. Hepimiz belli yaştayız. Sağglk sorunları olanlar oldu. Şuan için sadece kadın pazarında gibiyiz ama. Çevremizde bir farkındalık yarattı̆̆ımızı düşünüyorum. Kartalda Sokakta satış yapan kadınlar eskiden tezgahın başında durmaya utanıyordu. Çünkü evden dışarı bile doğru düzgün çıkmamışlardı. Ama sonradan, bir arkadaş ediniyorlar. Ben hastalandım ameliyat oldum 8 gün hastanede yanımda kooperatiften arkadaşlarım kaldı yanımda" (K2).

Katılımcılara kooperatife katılım gerekçeniz nedir sorusu sorulduğunda katılımcıların bir kısmı sosyalleşmek olduğunu vurgulamıştır. Bu bağlamda, katılımcılardan elde edilen görüşme sonucu birlikte sosyalleşmek temasına vurgusu yapan görüşler aşağıda belirtilmiştir:

Katılımcı 10, kooperatife katılım gerekçesi olarak sosyalleşmenin biraz daha ağır bastığını şu şekilde belirtmiştir:

"Benim tam anlamda hem ekonomi hem sosyalleşme, dört duvar arasından çıkma, birilerine ulaşma, sosyalleşmenin daha ă̆ır bastığı ve bunun yanında birazda ekonomi amaç taşıyor. Mahalledeki yoksul kadınlara ve çocuklara ulaşma. 
Zaten bununla yola çıktım. Öncelikle kendimi düşündüm. 4 çocuğum var. Bu dört duvar arasından nasıl dışarı çıkabilirim diye düşündüm. Kendimden yola çıkı diğer kadınları da göz önünde bulundurarak kooperatife katıldım" (K10).

Katılımc 16 ise, engelli kızından dolayı sınırlı bir sosyal hayatı olduğunu, kooperatif sayesinde sosyalleşebildiğini şu şekilde belirtmiştir:

"Hem sosyalleşmek için. Hem de kızımdan dolayı dışarıda çalışma imkanım olmuyor. Evde bir şeyler üretmeye çalışıorum. Kooperatif sayesinde evde üretebilecek örgü nakış işlerini yapabiliyorum" (K16).

Katılımcılara kooperatife katılım gerekçeniz nedir sorusu sorulduğunda katılımcıların bir kısmı maddi ihtiyaç olduğunu vurgulamıştır. Bu bağlamda, katılımcılardan elde edilen görüşme sonucu birlikte maddi ihtiyaç temasına vurgu yapan görüşler aşağıda belirtilmiştir:

Katılımc1 5, "Çocuklar büyüdü. Ben de bir iş yapmak istiyordum. Burayı buldum.", Katılımcı 6, "Maddi ihtiyacım olduğu için katıldım.", Katılımcı 13, "Maddi amaçlı katıldım.", Katılımcı 14, "Hem ekonomik hem de eşimden ayrılmıştım. Yaşamam için benim avantajımdı."şeklinde görüşlerini dile getirerek kooperatife katılım gerekçeleri maddi ihtiyaç olarak belirtmişlerdir.

\section{Kooperatiften Elde Edilen Gelir Miktarı}

Katılımclara kooperatiften aylık ne kadar gelir elde ediyorsunuz sorusu sorulduğunda, elde edilen veriler neticesinde kooperatiften elde edilen gelir miktarı kategorisi altında gelir elde edilmemesi ve parça başına ücret olmak üzere iki farklı kod oluşturulmuştur.

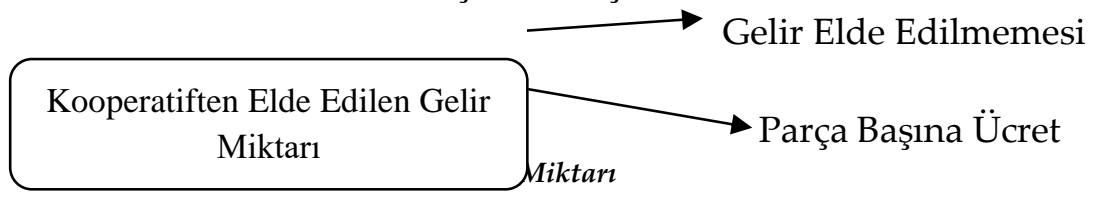

\subsection{Gelir Elde Edilmemesi}

Katılımcilara kooperatiften aylık ne kadar gelir elde ediyorsunuz sorusu sorulduğunda, katılımcıların bir kısmı kooperatiften her hangi bir gelir elde etmediğini belirtmiştir. Bu bağlamda, katılımcılardan elde edilen görüşme sonucu gelir elde edilmemesi temasına vurgu yapan görüşler aşağıda belirtilmiştir: 
Katılımc1 1, "Fazla bir gelirimiz yok çünkü çok yeniyiz.", Katılımc1 7, "Biz hiç gelir elde etmiyoruz. Satışlarımızı olduğumuz gibi okula bırakıyoruz çocuklarm eğitimine gidiyor hepsi." Katılımc1 8, "Henüz değil. Çünkü kendi kişisel gelirimi de kooperatife koydum." Katılımc1 12, "Gönüllüyüm ben gelir elde etmiyorum."

Katılımcı 2, eskiden eğitimci geliri elde ettiğini ama artık gelir elde etmediğini şu şekilde belirtmiştir:

"Eskiden eğitim veriyordum KEDV aracılı̆̆ı ile. $K E D V$ ' in verdiği eğitimin \% 75'ini ben alıyordum. Geri kalanını kooperatife bırakıyordum. Ama şuan eğitim veremiyorum sağlık durumumdan dolayı. Şuan aylık gelir elde etmiyorum" (K2).

Katılımcı 18 de, kooperatifinden şuan için bir gelir elde etmediğini şu şekilde belirtmiştir:

"Hiçbir gelir şuan elde etmiyorum. Benim amactm önce güzel ürünler üretelim. Tüketiciler buna karar versin. Yani para, kazanmak amaçh değil. Herkesin kendi geliri var. Burada birlikte başarılı işler yapabilmek amacımız" (K18).

\subsection{Parça Başına Ücret}

Katılımcilara kooperatiften aylık ne kadar gelir elde ediyorsunuz sorusu sorulduğunda, katılımcıların bir kısmı kooperatiften sipariş üzerine parça başı ücret elde ettiklerini belirtmiştir. Bu bağlamda, katılımcılardan elde edilen görüşme sonucu parça başına ücret temasına vurgu yapan görüşler aşağıda belirtilmiştir:

Katılımcı 3, "Çok izafi değişken bir şey. Hiç satmadığımız da var sattığımız da var. Ortalama dersek aylık 300 TL-400 TL aralığında değişiyor." Katılımc1 4, "800-900 TL. Memnunum."Katılımc1 5, "Bazen 400-500-600 TL olarak değişiyor." Katılımc1 6, "500 TL kazanıyorum.", Katılımc1 9, "Hiç söylemesek çünkü çok komik olacak. Aylı̆̆a varamıyoruz. Sipariş geldiğinde herkesin çalışma saatine göre a daletli bir şekilde dă̆̆tıyoruz. "şeklinde görüşlerini belirterek parça başına ücret elde ettiklerini belirtmiştir.

\section{Kooperatif Gelirinden Memnuniyet Durumu}

Katılımclara kooperatif gelirinden memnun musunuz sorusu sorulduğunda, elde edilen veriler neticesinde kooperatif gelirinden memnuniyet 
durumu kategorisi altında olumlu cevaplar ve olumsuz cevaplar olmak üzere iki farklı kod oluşturulmuştur.

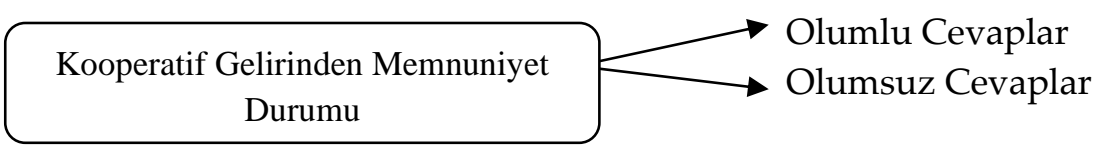

Şekil 5: Kooperatif Gelirinden Memnuniyet Durumu

\subsection{Olumlu Cevaplar}

Katılımclara kooperatif gelirinden memnun musunuz sorusu sorulduğunda, katılımcıların bir kısmı olumlu cevap vermiştir. Bu bağlamda, katılımcilardan elde edilen görüşme sonucu olumlu cevap şeklinde görüşlerini ifade edenler aşağıda belirtilmiştir:

Katılımcı 1, "Memnunum gelirden çünkü daha yolun başındayız.", Katılımc1 2, "Eğitim verdiğimde gelir elde ediyordum. Şuan sağllk durumumdan dolayı eğitim veremiyor gelir elde edemiyorum ama benim için bir arada olmak daha önemli.", Katılımc1 3 ve Katılımc1 4, "Evet, memnunum." , Katılımc1 6, "2 kişi çalışıyoruz evimiz kira zor tabi geçinmek. En azından aile bütçesine katkıda bulunuyorum.", Katılımc1 8, "Şuan yolun başındayız ama ben çok umutluyum.", Katılımcı 10, "Çok şükür gelirimiz geçmişe göre daha iyi.", Katılımcı 11, "Gelirimden Memnunum", Katılımc1 14, "Elde ettiğim gelirden çok şükür memnunum" şeklinde görüşlerini olumlu yönde ifade etmişlerdir.

\subsection{Olumsuz Cevaplar}

Katılımcılara kooperatif gelirinden memnun musunuz sorusu sorulduğunda, katılımcıların bir kısmı olumsuz cevap vermiştir. Bu bağlamda, katılımclardan elde edilen görüşme sonucu olumsuz cevap şeklinde görüşlerini ifade edenler aşağıda belirtilmiştir:

Katımc1 5, "Keşke daha artsa daha iyi olur", Katılımcı 7, "Elde ettiğimiz satıştan geliri okula bırakıyoruz. Keşke okulun geliri daha da artsa memnun olurum", Katılımc1 9, "Düzenli sipariş olmadı̆̆̆ için gelirimiz çok izafi memnunum diyemem", Katılımcı 12, "Ben çok memnun değilim", Katılımc1 13, "Gelirimin daha fazla olmasın isterim" şeklinde görüşlerini ifade etmiştir. 


\section{Kooperatifteki Çalışma Arkadaşlarının Katkısı}

Katılımcılara kooperatifteki çalışma arkadaşlarınızın size bir katkısı olduğunu düşünüyor musunuz sorusu sorulduğunda, elde edilen veriler neticesinde kooperatifteki çalışma arkadaşlarının katkısı kategorisi altında fiziksel destek ve psikolojik destek olmak üzere iki farklı kod oluşturulmuştur.

Kooperatifteki Çalışma Arkadaşlarının Katkısı

Şekil 6: Kooperatifteki Çalışma Arkadaşlarının Katkısı

\subsection{Fiziksel Destek}

Katılımcılara kooperatifteki çalışma arkadaşlarınızın size bir katkısı olduğunu düşünüyor musunuz sorusu sorulduğunda, katılımcların bir kısmı yaptıkları iş anlamında fiziksel destek yönünde katkısı olduğunu belirtmiştir. Bu bağlamda, katılımcılardan elde edilen görüşme sonucu fiziksel destek teması altında görüşlerini ifade edenler aşağıda belirtilmiştir:

K7, "Yardımlaşma oluyor. Birbirimizin ihtiyaçlarım gideriyoruz. Sosyalleşiyoruz. Evde ev işi yapmaya vaktimiz olmuyor", K8, "Her zaman oluyor. Bu bir ekip işidir. Yalnı olmaz bu işler. Hepsi ayrı becerileri var. Bir araya geldiğimizde çok güzel ürünler üretiyoruz", K10, "Muhakkak oluyor. Bireysel olarak hiçbir şey yapamayız. Onun hazzını alamayız. Yapsak bile ă̆ır aksak oluruz. Hep beraber yaptığında hem tadına varılmaz hem de o güç birliği daha bir başkadır" şeklinde görüşlerini belirterek çalışma arkadaşlarının fiziksel desteği sayesinde daha kaliteli ve hızlı bir şekilde ürün ürettiklerini ifade etmiştir.

\subsection{Psikolojik Destek}

Katılımcılara kooperatifteki çalışma arkadaşlarınızın size bir katkısı olduğunu düşünüyor musunuz sorusu sorulduğunda, katılımcıların bir kısmı psikolojik destek yönünde katkısı olduğunu belirtmiştir. Bu bağlamda, katılımclardan elde edilen görüşme sonucu psikolojik destek teması altında görüşlerini ifade edenler aşağıda belirtilmiştir: 
Katılımcı 3, manevi katkılarını olumlu ve olumsuz olacak şekilde her iki yönlü katkıda olduklarını şu şekilde belirtmiştir:

"Olumlu da oldu olumsuz da oldu, hayatta olduğu gibi. Pozitif ve negatif insanlar her yerde var. Çalışma hayatında okul hayatında da görürsün. Kendini sağlam tutacaksin. Böyle insanlarla aranda bir setin yani mesafen olacak" (K3).

Katılımcı 4 ise, kooperatifteki çalışma arkadaşları ile birlikte birbirlerinden hayata dair birçok şey öğrendiklerini şu şekilde ifade etmiştir:

“Türkiye'nin bütün illerinden arkadaşlarımız oldu. Kültür kaynaşması oldu. Herkesin yaşadığı farklı hayat deneyimleri var. Onları paylaşmak bana çok şey katıyor. İnsanın yaşı ve eğitimi ne olursa olsun insanın bir çocuktan bile öğrenebileceği çok şey var ben de buradan çok şey öğrendiğimi düşünüyorum" (K4)

Katılımcı 14 ise en zor zamanında kooperatifteki dostluk sayesinde hayata tutunabildiğini şu şekilde belirtmiştir:

"Benim gibi deliyi çekiyorlar ya Allah razı olsun. Beni hep dinlediler. Benimle ağladılar benimle güldüler. Burasının dostluğu bambaşka. Bazı kişilerin yeri bende bambaşkadır" (K14).

Katılımcı 15, çalışma arkadaşlarını motivasyon kaynağı olarak düşündüğünü şu şekilde ifade etmiştir:

"Manevi olarak katkı oluyor. İnsan hali. Her gün aynı motivasyonda olamıyoruz. Bazen moralimiz düşük oluyor. Oraya gidince kafa dă̆gllyor. Birbirimizi teselli ediyoruz. Yaşadığımız üzüntülerde sıkıntılarda birbirimize destek oluyoruz" (K15)

\section{Kooperatifin Çalışana Etkisi}

Katılımcılara kooperatifte çalışmanın kendilerine etkisinin olup olmadığ1 sorusu sorulduğunda, elde edilen veriler neticesinde kooperatifin çalışana etkisi kategorisi altında fiziksel etkisi ve psikolojik etkisi olmak üzere iki farklı kod oluşturulmuştur.

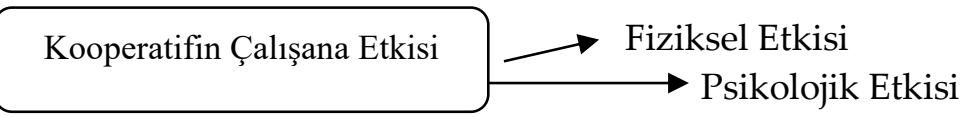

Şekil 7: Kooperatifin Çalışana Etkisi 


\subsection{Fiziksel Etkisi}

K9, K11 kooperatifte çalışmanın kendilerine olan fiziksel etkisine vurgu yapmiştır:

K9, kooperatif sayesinden yorgun olduğunu ve kendine ait boş vakit ayıramadığını şu şekilde belirtmiştir:

"Burada çalışmak güzel bir şey ama ben çok fazla emek verdiğim için yoruluyorum belli bir yaştan sonra. Haftada bir gün kendime ayıracă̆ım diyorum onu bile yapamıyorum. Mesela ben resim yapmayı çok seviyorum. Bu hobime vakit ayıramıyorum" (K9).

K11 ise "Daha sağlıkl, arkadaş çevren var sosyal hissediyorum."diyerek kendini kooperatif sayesinde daha sağlıklı hissettiğini belirtmiştir.

\subsection{Psikolojik Etkisi}

K9 ve K11 dışındaki diğer katılımcılar kooperatifin kendilerine olan psikolojik etkisini ifade etmişlerdir. Katılımcılardan bazılarının görüşleri şu şekildedir:

$\mathrm{K} 1$, kooperatif sayesinde hem toprak ile ilgilenmenin hem de toplumdan kopmamanın kendisini mutlu hissettirdiğini şu şekilde belirtmiştir:

“Çok mutluyum. Çünkü daha önce basın camiasındaydım. Senelerce bir ulusal gazetede çalıştım. Radyo Televizyon programlarmda yıllarca muhabirlik yaptım. Ama kooperatifte iş farkl. Çünkü ayağının biri toprakta oluyor diğer aya$\breve{g}$ ın ise toplum içerisinde olması harika bir duygu. Çok mutluyum bu yüzden" (K1).

K10, herkesin eşit şartlar altında çalıştığını ve rahat bir çalışma ortamı olduğunu şu şekilde belirtmiştir.

"Kendi işim her şeyden önce. Patronum yok, müdürüm yok bă̆ıranım çă̆granım yok. Herkes eşit şartlar altında. Herkes kendisine uygun olduğu saatte geliyor ve emeğinin karşılı̆̆ını alıyor. Aslında kooperatif bulunmaz bir nimettir. Hiçbir işyerinde, kişinin kendi işi de olsa belli saatte işine gitmek zorundadır. Ama burada kolektif bir çalışma ortamı var. Ben müsait değilsem gidemezsem arkadaşım gidiyor. Bunun karşılığını az da olsa alabiliyor. Bu yüzden kooperatifçilik başkadır" (K10). 


\section{Yoksulluk Algisı}

Katılımcılara yoksulluk nedir sorusu sorulduğunda, elde edilen veriler neticesinde yoksulluk algısı kategorisi altında fakirlik, tembellik, sevgi yoksulluğu ve eğitim yoksulluğu olmak üzere dört farklı kod oluşturulmuştur.

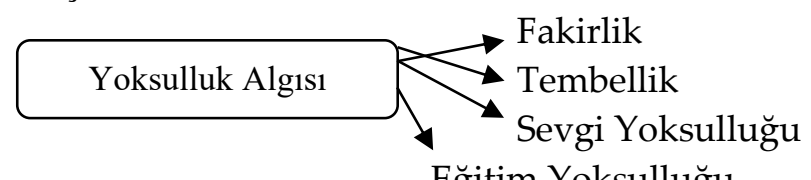

Şekil 8: Yoksulluk Algısı

Eğitim Yoksulluğu

\subsection{Fakirlik}

Katılımclara yoksulluk nedir sorusu sorulduğunda katılımcılardan bazıları fakirlik teması altında görüşlerini belirtmiştir:

K3, "Zorluk demek, açlık ve muhtaçlık demektir", K4, "Yoksulluk göreceli bir şey. İsteyip de elde edemeyeceğimiz her şey yoksulluk belirtisidir. Maddi ve manevi sadece maddi anlamda değil bence", K5, "Yoksulluk hayat şartlarm altında yaşamak. İstediğin şeyleri satın alamamak istediğin yerlere gidememek.", K6, "Yoksulluk çocuklarına istediklerini alamamak. Başkasının giysilerini giydirmek zorunda kalmak demek", K7, "Yoksulluk, istediğini alamamak.", K9, "Insanın madden ve manen istediğ i bir şeye ulaşamaması durumudur.", K13, "Evin ihtiyacın göremiyorsun çocuklarının önemli ihtiyaçlarım karşılayamıyorsan kiranı ve faturanı ödeyemiyorsan yoksulsun demektir." ,K14, "Parasızlı demek. Tuvalette bile $1 \mathrm{~T}$ giriş. Paran yoksa yoksulsun. Paran varsa her yer senin olur. Paran yoksa özgürlüğ̈̈n yok bir kere.", K16, "Yoksulluk benim için çok şey demek. Mesela çocuğunuzun bir hastalık durumu var ve bir eğitim alması gerekiyor. Ama siz bu eğitimi aldıramıyorsunuz. Bu bir yoksulluk benim için.", K17, "Yoksulluk, iyi bir şey değil. Bunu yaşayan bilir. Biz elimizden geldiğgi kadar yoksullara destek olmaya çalışıyoruz." şeklinde görüşlerini belirterek yoksulluğu fakirlik olarak vurgulamışlardır. 


\subsection{Tembellik}

K8, K12 ve K18 yoksulluk nedir sorusu sorulduğunda tembellik temas1 altında görüşlerini belirtmiştir:

K8, yoksulluğun tembellik olduğunu ve çalışmamanın yoksulluğa sebep olduğunu şu şekilde ifade etmiştir:

"Yoksulluk, bir yerde çaresizlik demek. Ama çalışan insan yoksul olmaz. Aza kanaat ederseniz yoksul hissetmezsiniz. Kendi gıdanızı kendi üretirseniz. Aç kalmazsınız. 100 metre topră̆ı olan aç kalmaz" (K8).

K12, "Yoksulluk bana göre çalışmamak demek", K18 de yoksulluğun tembellik demek olduğunu şu şekilde ifade etmiştir:

"Yoksulluk tembellikten kaynaklanıyor. Siz bir şey yapmazsanız yoksulluk sizin tüm ruhunuza yapışır. Yoksulluk üretmemek demektir. Gereksiz harcamalar demek. Yoksulluğun kader olduğuna inanmıyorum" (K18).

\subsection{Sevgi Yoksulluğu}

K15, yoksulluğu sevgi yoksulluğu boyutundan ele alarak görüşünü şu şekilde ifade etmiştir:

"Yoksulluk deyince hepimizin aklina açlık, giysisizlik ve evsizlik geliyor. Yoksulluk aslında sevgi yoksunluğu olarak düşünüyorum. O kadar fazla insanda görüyorum ki sevgi yoksunluğunu. Çoğu insan tatmamış bile sevgiyi. Insanlarm en çok buna doymasını isterim. Sevgi doygunluğu en önemlisi" (K15).

\subsection{Eğitim Yoksulluğu}

K10 yoksulluğu eğitim yoksulluğu boyutundan ele alarak görüşünü şu şekilde ifade etmiştir:

"Bana göre, hem ekonomik hem bilinç olarak yoksulluk diye bir şey var. Mesela toplumun bize verdiği rol annelik ve çocuk yetiştirmek. Biz çocukları ne kadar yeterli yetiştirdik. KEDV sayesinde mahalle anneliği eğitimini aldık. Bu eğitimden sonra çocuklarımı ne kadar eksik yetiştirdiğimi gördüm. Zannediyordum ki çocuklarımı bir anne olarak ne kadar iyi yetiştirdim. Ama o eğitimlerden sonra kendinin farkına varryorsun" (K10). 


\section{Yoksul Hissetme Durumu}

Katılımclara kendinizi yoksul hissediyor musunuz sorusu sorulduğunda, elde edilen veriler neticesinde yoksul hissetme durumu kategorisi altında, olumlu cevaplar ve olumsuz cevaplar altında iki kod oluşturulmuştur.

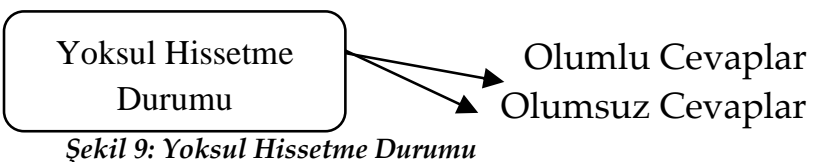

\subsection{Olumlu Cevaplar}

Katılımcılara kendinizi yoksul hissediyor musunuz sorusuna karşllık görüşlerini olumlu cevap kodu altında şu şekilde belirtmiştir:

K1, "Geçmişte çok yoksul hissettim ama şuan da zaman zaman yoksul hissediyorum. Bazen bir kenara çekiliyorum. Diğer insanlarm açlı̆̆ da beni yoksul hissettiriyor"diyerek sürekli bir yoksulluk içinde olmadığını ama yoksulluğu hissettiğini belirtmiştir.

K4, yoksulluğu kooperatifteki olanak ve imkanlar açısından değerlendirerek bu doğrultuda kendini yoksul hissettiğini şu şekilde belirtmiştir:

"Ben kooperatifle ilgili kendimi dönem dönem yoksul hissediyorum. Kooperatifin istediğ i yere gelememesi ihtiyaçlarımızın temin edilememesi kooperatif açısindan yoksul hissediyorum. Kooperatifin olanaksızlıklar bana böyle hissettiriyor" (K4).

\subsection{Olumsuz Cevaplar}

Katılımcılara kendinizi yoksul hissediyor musunuz sorusuna karşılık görüşlerini olumsuz cevap kodu altında şu şekilde belirtmiştir:

$\mathrm{K} 2$, "Geçmişte yoksul olduğum çok zamanlar oldu ama şuan hissetmiyorum.", K3, "Hayır şuanda yoksul hissetmiyorum.", K5, "Kendimi şuan yoksul hissetmiyorum.", K7, "Kendimi hiç yoksul hissetmedim.", K8, "Hiç yoksul hissetmedim. Ben tek başıma üç tane çocuğumu büyüttüm hiç kimseden destek almadan hatta.", K9, "Geçmişte evet kendimi yoksul hissettiğim zamanlar oldu. Fakat 
şuan her şey için Allah'a şükrediyorum.", K12, "Hiçbir zaman yoksul hissetmedim. Genç kızlı̆̆ımdan beri hep çalıştım hiç oturmadım." , K13, "Zaman zaman oluyor." ,

K14, kendisin, yoksul hissettiği zamanlarda kooperatifteki arkadaşlarından borç para aldığını şu şekilde belirtmiş̧ir:

"Zaman zaman yetemediğim yerde yoksul hissediyorum. Benim bir kızım var. Para istediğinde ona para veremediğim zaman sıkıntı hissediyorum. Ama Arkadaşlarım ATM oluyor bazen benim için. Beni sağolsunlar ihtiyacım olduğunda beni geri çevirmiyorlar" (K14).

K17, "Çok zengin değilim. Hiçbir şeye muhtaç da değilim. O kadar ihtiyaç sahibi insan gördüğünde kendini daha zengin görüyorsun"diyerek çevresindeki yoksul insanları fark ettikçe kendini yoksul hissetmediğini ifade etmiştir.

\section{Kooperatifin Eksiklikleri}

Katılımclara kooperatifinizde hangi eksiklik tamamlansa daha mutlu olursunuz sorusu sorulduğunda, elde edilen veriler neticesinde kooperatifin eksiklikleri kategorisi altında, maddi destek, takım ruhu, sürdürülebilir pazarlama ve SGK hakkı olmak üzere dört kod oluşturulmuştur.

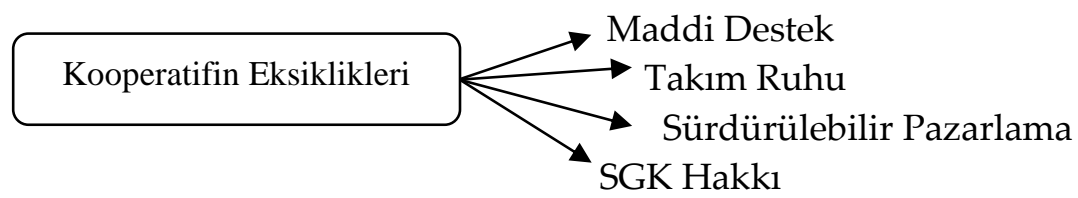

Şekil 10: Kooperatifin Eksiklikleri

\subsection{Maddi Destek}

Katılımcılardan bazıları yaşadıkları eksiklikleri maddi destek kodu altında şu şekilde ifade etmiştir:

K4, parçası oldukları kooperatifte tüm çalışanlarından kendilerinden kattıkları bir eşya olması sebebiyle neden bu kadar sahiplendiklerini belirterek daha bir modern çalışma ortamında çalışmak istediğini şu şekilde ifade etmiştir: 
"Buraya gelen arkadaşlarımın ihtiyacın karşılamak beni mutlu ederdi. Tama çalışma ortamımı derme çatma değil de modern olması beni mutlu ederdi. Ama ben yine de mutluyum. Dar gelirli kadınlarla çalışıyorum. Evlerimizde kullanmadiğımız eşyalarla bu atölyeyi oluşturduk Bu atölyede herkesin kendi evinden getirdiği bir eşyası var. Bir parçası var bu eşyalar kadının bir ruhunu da taşıdığını düşünüyorum. Belki de bu yüzden herkes bu atölyeyi bu kadar sahiplendi bilemiyorum. Her şey tepeden inmiş hazır olsa belki de bu kadar sahip çıkmazdık ve mutlu da olamazdik" (K4).

K14, maddi destek verilerek çalışma ortamının modernleştirilmesi gerektiğini şu şekilde ifade etmiştir:

"Isınmamız yok. Masalar ve kasalarımız iyi değil. Daha temiz ortamız olsa. Bulaşık makinemiz yok. Sıkıntımız çok da dinleyen yok. Buraya el atan yok. Burası yalnız başına bir kooperatif. Çok büyük destek olmaları lazım. Düzen yok ama. Ben 10 seneden beri buradayım. Şahıs gözetmiyorum asla da gözetmem. Ĕ̆er ben bu ilçede yaşıyorsam kimse ayrımcillk yapmamall. Yok denilmemeli. Kasalarımızın haline bak. Kadın eşinin silikonların getiriyor kendi tamir etmeye çalışıyor. Emeğimize saygı duyulmalı. Kırık kasayla çalışıyorsam iki sandalye üst üste koyup oturmuşum. Daha başka bir şey demiyorum. Diğer arkadaşım komşusundan sandalye getiriyor yoldaki sehpayı getiriyor atölyeye lazım deyip. Yoldaki kartoncuları geçti. Eksikliğimiz çok fazla" (K14).

\subsection{Takım Ruhu}

K2 ve K3 kooperatiflerinde takım ruhunun eksik olduğunu şu şekilde ifade etmiştir:

$\mathrm{K} 2$, kooperatifindeki takım ruhu yerine bireyselciliğin ön plana çıkt1ğını, takım ruhuna geri dönmeleri gerektiğini belirterek bu durumun kooperatifindeki bir eksiklik olarak şu şekilde ifade etmiştir:

"Biraz daha birlik olsak ve girişimci olsak daha mutlu olurum. Illk kuruluşumuzda takım ruhumuz vardı ama şuan bu yok. Acaba kadın ürünleri pazarında herkes bireysel ürün sattığ için mi acaba kendimce sorguluyorum. Herkesin bireysel kazancı ön plana çıktı. Yapımız da böyle gelişti. Bu durum da bireyselliği tetikledi acaba. Nasıl toparlanır bilmiyorum ama toparlanacak kişi ben miyim onu da bilmiyorum" (K2).

$\mathrm{K} 3$, kooperatifte takım ruhunun eksikliğini şu şekilde ifade etmiştir: 
"Daha katılımo arkadaşlarımız olsa daha iyi olur. Biz bunu 3-4 kişi ile yapıyoruz. Herkesin bu taşın altına elini koymasını isterdik. Ama bunu sağlayamadık. Takım çalışması bu biraz eksik bizde" (K13).

\subsection{Sürdürülebilir Pazarlama}

K15 ve K16 kooperatifte sürdürülebilir pazarlama eksikliğine sahip olduğunu şu şekilde ifade etmiştir:

K15, "Düzenli bir sipariş almak beni mutlu eder. Bize on tane kadın gelse sen de gel bunu yap diyebiliriz. Daha mutlu olurum." , K16, "Sürekli işimiz olsa. Benim gibi evinde iş yapmak zorunda kalan daha çok kadına ulaşılsa çok mutlu olurum."

\subsection{SGK Hakk1}

K5, K6 ve K13 aldıkları ücretlerin daha yüksek olmasını ve SGK haklarının olmasını istedikleri yönünde görüş belirtmiştir.

K6, "Maaşımız daha iyi olsa SGK yarım kaldı. Keşke onu ödeyebilsem daha memnun olurdum."

\section{Sonuç ve Öneriler}

Bu çalışmada, İstanbul' da ki kadın kooperatiflerinin kadın yoksulluğuna olan etkisinin analiz edilmesi için kadın kooperatifi çalışanları ile yarı yapılandırılmış görüşme gerçekleştirilmiştir. Gerçekleştirilen yarı yapılandırılmış görüşme sonucunda katılımcıların kooperatif algısı değerlendirildiğinde, çoğunluğu kooperatifin sosyal fayda yönünü vurgulamıştır. Katılımcıların kooperatife katılım gerekçesi sorulduğunda, çoğunluğu sosyalleşmek ve farkındalık yaratmak şeklinde görüşlerini ifade etmiştir. Katılımcıların kooperatiften elde ettikleri aylık gelir miktarı sorulduğunda katılımcların çoğunluğu parça başına ücret elde ettikleri yönünde görüş belirtmiştir. Katılımcılara, çalışma arkadaşlarınızın size herhangi bir katkısı oluyor mu sorusu sorulduğunda, on iki katılımcı çalışma arkadaşlarının kendilerine olan psikolojik katkısını, altı katılımcı ise fiziksel yönde katkısı olduğunu belirtmiştir. Katılımcılara kooperatifte çalışmanın kendilerine olan etkisi sorulduğunda, iki katılımcıdan biri yorgun hissettirdiğini 
diğeri daha sağlıklı hissettirdiğini belirterek fiziksel etkisi olduğu yönünde; on altı katılımcı ise mutlu, sosyal, güçlü ve özgüvenli gibi ifadeler kullanarak psikolojik etkisi olduğu yönünde görüş belirtmiştir. Katılımc1lara yoksulluk nedir sorusu sorulduğunda, on iki katılımcı fakirlik, üç katılımcı tembellik, bir katılımcı sevgi yoksulluğu, diğer katılımcı ise eğitim yoksulluğu olarak görüş belirtmiştir. Katılımcllara kendinizi yoksul hissediyor musunuz sorusu sorulduğunda, yedi katılımcı yoksul hissettikleri yönünde olumlu; on bir katılımcı ise yoksul hissetmedikleri yönünde olumsuz görüş belirtmiştir. Katılımcılara kooperatifinizdeki eksiklik nedir sorusu sorulduğunda, sekiz katılımcı maddi desteğe, iki katılımcı takım ruhuna, iki katılımcı sürdürülebilir pazarlığa, diğer iki katılımcı ise SGK hakkına ihtiyaç duyduklarını ifade etmiştir. Bu çerçevede, şu önerilerde bulunabilir:

- Kadın kooperatif çalışanlarının SGK hakkından mahrum kalmaları çalışanların motivasyonunu düşürmektedir. Temel özlük haklarından biri olan SGK kaydından mahrum kalmaları düzenli bir gelir elde etse de kooperatife karşı aidiyet duygularını zedelemektedir. SGK ödemeleri konusunda kadın kooperatifi çalışanları için pozitif ayrımcılığa dayalı yasal düzenlemeler yapılabilir.

- Kadın kooperatiflerinin sürdürülebilir üretim yapabilmesi ve pazarlayabilmesi açısından ücretsizlik danışmanlık hizmeti verilebilir.

- Kadın kooperatiflerinin gelişebilmesi ve tutunabilmesi önündeki en büyük engellerden birinin sermaye yetersizliği olması sebebiyle, yerel yönetimlerin kadın kooperatiflerine bütçelerinden yardım etmesi yönünde yasal düzenlemeler gerçekleştirilebilir.

- Kadın kooperatifleri çalışanlarına kooperatifçilik ve girişimcilik eğitimi vererek aralarındaki dayanışma duygusu arttırılabilir.

- Kadın kooperatiflerinin ticari işletme olarak görülmemesi sebebiyle banka kanalı ile finansal kaynak bulmada zorlandıkları öğrenilmiştir. Bankalara, kadın kooperatiflerine finansal kaynak sağlamaya yönelik düzenlemelerin gerçekleştirilmesi adına anlaşmalar yapılabilir. 


\title{
EXTENDED ABSTRACT
}

\section{The Effect of Women's Cooperatives in İstanbul on Women's Poverty}

\author{
H. Yunus Taş - Esra Nur Kazar \\ Yalova University
}

Poverty is a multidimensional concept with different definitions in different societies, times and cultures. Poverty definitions also change according to the criterion taken into account when making poverty definitions. The concept of women's poverty as a sub-dimension of poverty, states that women experience poverty more deeply and more severely than men and emphasize their disadvantageous position in society. Since the 1970s, attention has been drawn to women's poverty and the need for special social policy tools has been created for this disadvantaged population. Different employment policies are being formed as active and passive as social policy tools in preventing women's poverty. Women cooperatives which are a social policy tool in Turkey has begun to make improvements in women's economic and social life since 2001 and has begun to attract attention. Women's co-operatives are able to include housewives who are far from employment and who are at higher risk of poverty, and this has increased the interest in women's co-operatives. In this sense, the main purpose of this study is to analyze the impact of women's co-operatives on women's poverty in the context of interviews with women's co-operatives.

In this context, in-depth interview method which is one of the qualitative data collection techniques was chosen in this study. In-depth interviewing is a method in which open-ended questions take place and the interviewer shares his / her personal views. The aim of the in-depth interview is to reach the reasons underlying the personal opinions of the participants (Baş and Akturan, 2017: 113). For this purpose, a semi-structured interview form was administered to 18 female employees from 6 women's co-operatives operating in Istanbul. MAXQDA 2018 qualitative data analysis program was used in the analysis of the interviews.

In this study, semi-structured interview technique, which is one of the indepth interview techniques, was applied. The sample of the study is for the purpose of the sample. A semi-structured interview form consisting of nine 
questions was administered to 18 participants working in women's co-operatives in Istanbul. In order to evaluate the participants' perceptions of the cooperative and poverty and the material and moral contribution of the cooperative to them, the following questions were sought in the form of semi-structured interview:

- What comes to your mind firs when you say the cooperative?

- What is your reason for joining the cooperative

- How much income do you earn per month from the cooperative?

- Are you satisfied with your cooperative income?

- Do you think your co-workers in the cooperative have contributed to you?

- Do you think your work in the cooperative contributes to you?

- What do you think is poverty?

- Do you feel poor?

- Which deficiency in your cooperative would be more successful?

As a result of the semi-structured interview, when the participants' perceptions of the cooperative were evaluated, the majority emphasized the social benefit aspect of the cooperative. When the reasons for participation in the cooperative were asked, the majority of the participants expressed their views on socializing and raising awareness.

When asked about the monthly income of the participants from the cooperative, the majority of the participants stated that they were paid per piece. When the participants were asked if your colleagues had any contribution to you, twelve participants stated that their colleagues had a psychological contribution and six participants had a physical contribution.

When the participants were asked about the effect of working in the cooperative, one of the two participants stated that it made them feel tired and the other had a health effect. Sixteen participants stated that they have psychological effects by using expressions such as happy, social, strong and confident.

When asked what poverty is, twelve participants expressed poverty, three participants' laziness, a participant poverty of love, and the other participant expressed poverty of education. When asked if the participants feel poor, seven participants were positive that they felt poor; eleven participants stated that they did not feel poor. When asked what the deficiency in your cooperative is, eight participants stated that they needed financial support, two participants needed team spirit, two participants needed sustainable bargaining 
and the other two participants needed the right to SSI. Within this framework, the following recommendations can be made:

- The deprivation of women's co-operative workers from the right to SSI decreases their motivation. Being deprived of the SSI registration, which is one of the basic personal rights, does damage their sense of belonging to the cooperative, although they earn a regular income. Regarding SSI payments, legal regulations based on positive discrimination can be made for women's cooperative employees.

- In order to ensure sustainable production and marketing of women's cooperatives, free consultancy service can be provided.

- Since one of the biggest obstacles to the development and retention of women's co-operatives is the lack of capital, legal arrangements can be made for local governments to help women's co-operatives from their budgets.

- A sense of solidarity can be increased by providing cooperative and entrepreneurship training to women co-operatives.

- It was learned that women's co-operatives had difficulty in finding financial resources through the bank channel as they were not considered as commercial enterprises. Agreements may be made in order to make arrangements for banks to provide financial resources to women's cooperatives.

\section{Kaynakça / References}

Baş, T. ve Akturan, U. (2017). Sosyal bilimlerde bilgisayar destekli nitel araştırma yöntemleri. (3. Baskı). Ankara: Seçkin Yay.

Chant, S. (2008). The feminisation of poverty and the 'feminisation' of the antipoverty programmes: Room for revisin?. Journal of Development Studies, 44(2), 165-197.

Gerşil, G. (2015). Küresel boyutta yoksulluk ve kadın yoksulluğu. Yönetim ve Ekonomi Dergisi, 22(1), 159-181.

G20 Ülkelerinde Kooperatifçilik (2015). http://koop.gtb.gov.tr/data/5697bd461a79f5d2d018c237/G20_kitapcik\%2002.12.2015\%20son\%20 son\%20son.pdf, Erişim Tarihi: 10.07.2019.

Kardam, F., ve İ. Yüksel. (2004). Kadınların yoksulluğu yaşama biçimleri: yapabilirlik ve yapabilirlikten yoksulluk. Nüfus Bilimleri Dergisi. 26, 4572. 
Kocabaş, Y., Ö. (2003). Türkiye'de kooperatifçilik düşüncesinin gelişimi. tarım ekonomisi dergisi, 8, 15-24.

Koçtürk, O., M. (2006). Türkiye'de kooperatiflerin vergilendirilmesi. Yönetim ve Ekonomi Dergisi, 13(2), 119-136.

Kooperatifçilik ve Kadın Kooperatifleri (2012). http://koop.gtb.gov.tr/data/51f7a6fe487c8e14b4454624/Kooperatif\%C3\%A7ilik\%20ve\%20Kad\%C4\%B1n\%20Kooperatifleri\%20Kitap\%C3\%A7\%C4\%B1k\%2018.12.2012.pdf, Erişim Tarihi: 10.07.2019

Semerci, A. (2015). Türkiye' de çiftçi örgütleri: Tarımsal amaçlı kooperatifler örneği. Namık Kemal Üniversitesi Tekirdă̆ Ziraat Fakültesi Dergisi, 12(1), 65-73.

Serinikli, N. (2016). Kadın yoksulluğunu önlemede girişimciliğin önemi: kadin kooperatifleri ve mikro kredi uygulamaları. Balkan Sosyal Bilimler Dergisi, 5, 598-609.

Sicchia, S., R. ve Maclean, H. (2006). Globalization, povert and women's health, mapping the connections. Canadian Journal of Public Health, 97(7), 69-71.

Topalhan, T. ve F. Yeşilkaya (2017). Kadın yoksulluğunu etkileyen faktörlerin panel veri analizi ile belirlenmesi. Karatahta İş Yazıları Dergisi, 9, 5582.

Ulutaş, Ç., Ü., (2009). Yoksulluğun kadınlaşması ve görünmeyen emek. Çalışma ve Toplum Dergisi, 2, 25-40.

Yüksel Arabacı, R. (2014). Sosyal Politika. Aysen Tokol ve Yusuf Alper (Ed.). Gelir Dağılımı ve Yoksulluk içinde (176-202). Bursa: Dora Yay.

\section{Kaynakça Bilgisi / Citation Information}

Taş, H. Y. ve Kazar, E. N. (2019). İstanbul'daki kadın kooperatiflerinin kadın yoksulluğuna etkisi. OPUS-Uluslararası Toplum Araştırmaları Dergisi, 13(19), 1836-1863. DOI: 10.26466/opus.590744 